\title{
POTENTIAL OF BIOWASTES TO REMEDIATE DIESEL FUEL CONTAMINATED SOIL
}

\section{AGAMUTHU P. DADRASNIA A. *}

\author{
Institute of Biological Sciences \\ Faculty of Science, University of Malaya \\ Kuala Lumpur, 50603, Malaysia
}

Received: 30/01/13

Accepted: 14/03/13
$1,{ }^{*}$ to whom all correspondence should be addressed: e-mail: are.dadrasnia@gmail.com

\section{ABSTRACT}

The unintended release of hydrocarbons into the environment can negatively impact human and animal health, and could further change the characteristics of soils. The aim of the present work was to investigate the rate of biodegradation at 10 and $20 \%$ diesel fuel in contaminated soil amended with $10 \%$ of three different organic wastes (tea leaf, soy cake, and potato skin) for a period of 126 days. 82 and $25 \%$ oil loss was recorded in soil amended with soy cake at $10 \%$ and $20 \%$ oil pollution, respectively. Diesel fuel utilizing bacteria counts were high in all organic wastes amended treatments, ranging from $150 \times 10^{6}$ to $176 \times 10^{6} \mathrm{CFU} \mathrm{g}{ }^{-1}$ of soil, compared with the unamended control soil which gave $23 \times 10^{6} \mathrm{CFU} \mathrm{g}^{-1}$.

Dehydrogenase activity in soil was markedly enhanced by the application of organic wastes. Diesel oil composition monitored by GC/MS indicated complete degradation of $n-C_{9}-C_{12}$. First-order kinetic model showed that among the three organic wastes used, soy cake had the highest biodegradation rate constant of 0.153 day $^{-1}$ at $10 \%$ oil pollution, while biodegradation rate was 0.033 day $^{-1}$ at $20 \%$ oil pollution. The results showed there is potential for soy cake, potato skin and tea leaf to enhance biodegradation of diesel in contaminated soil.

KEYWORDS: Bioremediation, Diesel fuel, Hydrocarbon, Organic waste.

\section{INTRODUCTION}

Contamination as a result of petroleum leakages in both underground and above ground tanks via industrial and transportation processes, are hazardous to human, animals and plants (Adesodun and Mbagwu, 2008; Bamforth and Singleton, 2005; Hamdi et al., 2007). Global production of crude oil is estimated at more than twelve million metric tons annually (EIA, 2011). It has been reported that 1.7 to 8.8 million metric tons of petroleum hydrocarbon escapes into the soil and world's water bodies annually. Methods for treating petroleum contaminations are through; chemical, physical and biological processes. Both physical and chemical methods of treatments are expensive, compared to biological treatments (Bioremediation); the use of microorganisms to remove hydrocarbon pollutants from the environment (Collin, 2001). This method is recognized to be efficient, cost effective and environmentally sound treatment. Bioremediation of contaminants can be accomplished by two methods; bioaugmentation and/ or biostimulation. In some previous studies, bioaugmentation (addition of commercial microbial cultures), compared with biostimulation (adding nutrients), did not significantly enhance rates of oil biodegradation (Bento et al., 2005; Selina and lan, 2005). Numerous research projects have addressed the successful applications of biostimulation in the remediation of hydrocarbon-contaminated soil and enhanced degradation (Abioye et al., 2009; Adesodun and Mbagwu, 2008; Akinde and Obire, 2008; Bento et al., 2005; Manuela et al., 2012). Therefore, the combined actions of biostimulation through compost addition and bioaugmentation provided a good option for removal of total petroleum hydrocarbon (TPH) from diesel-contaminated soil (Taccari et al., 2012). Many factors can be affected by the rate of TPH, such as lack of essential nutrients, especially nitrogen and phosphorus. Some nutrient samples like inorganic fertilizer's, compost, biowastes, and manure have been used in biostimulation studies (Adesodun and Mbagwu, 2008; Dadrasnia and Agamuthu, 2010; Namkoong et al., 2002; Pankrantz, 2001). Antai (1989) 
reported high rate of biodegradation of hydrocarbon's in crude oil contaminated soil with $20 \%$ and $10 \%$ compared with those contaminated with $40 \%$ and $30 \%$ oil within a period of one year. Positive effects of nitrogen amendment on petroleum hydrocarbon degradation and microbial activity have been demonstrated (Antai and Mgbomo, 1989). This study is aimed at evaluating three different organic wastes (biowastes); Tea leaf (TL), Potato skin (PS) and Soy cake (SC) as supplements for bioremediation, to enhance the biodegradation of diesel oil polluted soil. The objectives include the determination of the rate of biodegradation of the diesel in the contaminated soil and the half-life of the diesel oil degradation using kinetic model. Isolation and screening of some potential microorganisms on the diesel oil degradation, in both contaminated and uncontaminated soil was also carried out.

\section{MATERIAL AND METHOD}

The soil used in this study, (silty loam), was obtained from the garden section of Asia-Europe Institute, University of Malaya, Kuala Lumpur. It was air dried and sieved through a 2-mm mesh sieve. The organic wastes used in this study were collected from different locations; tea leaf $(T L)$ and potato skin (PS) was collected from the IGS (Institute of graduate studies) canteen, University of Malaya, while the soy cake (SC) was made in the laboratory. Physicochemical properties of organic wastes and soil employed were determined using standard methods. Triplicate determinations were made.

\section{Bioremediation Setup}

Concentration range of the oil used for the treatment is within $5-25 \%$ as reported by earlier researchers (ljah and Antai, 2003a). $1.5 \mathrm{~kg}$ of fresh soil was placed in plastic poly bags, labeled A to $\mathrm{E}$ and contaminated with 10 and $20 \%(\mathrm{w} / \mathrm{w})$ diesel fuel $\left(100,000\right.$ and $\left.200,000 \mathrm{mg} \mathrm{kg}^{-1}\right)$. After 2 days, $10 \%$ each of organic wastes (TL, SC and PS) were added into each of the oil-polluted soil. These soil were mixed daily to provide sufficient aeration and moistened by the addition of water every other day to adjust the water holding capacity at $60 \%$ throughout the experimental period. The soil bags were incubated at room temperature $\left(30 \pm 2^{\circ} \mathrm{C}\right)$. The controls with only soil and diesel fuel, additional same day "twice autoclaved" control treatment $(E)$ at $\left(121{ }^{\circ} \mathrm{C}\right.$ and 15 psi for $\left.1 \mathrm{~h}\right)$ with the addition of $0.5 \%(\mathrm{w} / \mathrm{w}) \mathrm{NaN}_{3}$ to determine the non-biological loss on diesel oil from the soil. All the treatments were set up in triplicates.

\section{Sampling}

The contaminated soils were sampled once in every two weeks for a period of 126 days. To determination the total petroleum hydrocarbon in soil. Aerobic heterotrophic bacteria (AHB) and diesel utilizing bacteria (DUB) were isolated, counted and identified.

\section{Enumeration of Bacteria and Identification}

0.1 mLof serially diluted soil samples were plated out on nutrient agar medium (Oxide) for isolation of aerobic, heterotrophic bacteria with $50 \mu \mathrm{g} \mathrm{mL}^{-1}$ fungazol to suppress the growth of fungi. Plates were incubated at $32{ }^{\circ} \mathrm{C}$ for 24 , hours after which the colonies were counted. Diesel fuel utilizing bacteria in the soil samples were enumerated using oil agar (OA) (Zajic and Supplisson, 1972). The bacterial isolates were characterized using Biolog Microstation method (Ruan et al., 2005).

\section{Measurement of diesel fuel in soil}

The extent of diesel biodegradation in soil was determined by gravemtric method using rotary evaporation. Percentage of degradation of diesel fuel was calculated using the following formula (ljah and Ukpe, 1992):

$\%$ biodegradation $=[\mathrm{TPH}$ control- TPH treatment $/ \mathrm{TPH}$ control $] \times 100$, where TPH is total petroleum hydrocarbon.

\section{$\mathrm{CO}_{2}$ production and dehydrogenase activity}

$\mathrm{CO}_{2}$ production was determined by sampling the headspace of the sealed Wheaton bottle containing sample of soil, oil and the organic supplement. Using gas chromatography (GC-8A) with a thermal conductivity detector (Miles and Doucette, 2001). Temprature of the GC were; detector $110{ }^{\circ} \mathrm{C}$, injector $110^{\circ} \mathrm{C}$ and column at $130{ }^{\circ} \mathrm{C}$. Dehydrogenase activity was determined by monitoring the 
rate of reduction of 2,3,5-triphenyltetrazolium chloride (INT) as a substrate (Margesin and Schinner, 2005).

\section{Seed germination toxicity test}

Ten viable seeds of lettuce (Lactuca sativa L.) were placed evenly on each Petri dish and covered with dry sand for 7 days. The numbers of seedlings that emerged from the surface of the sand was counted and recorded (Banks and Schultz, 2005). Germination index of lettuce seed on the remediated soil was calculated using the formula of (Millioli et al., 2009).

$$
\text { Germination index }(\%)=\frac{(\% \mathrm{SG}) \times(\% \mathrm{GR})}{100}
$$

$\% \mathrm{SG}=(\% \mathrm{EG} / \% \mathrm{CG}) \times 100$

$\% \mathrm{GR}=(\mathrm{GERm} / \mathrm{GERCm}) \times 100$

where \% SG = seed germination, \% GR = growth of the root, \% $E G$ = germination on contaminated soil, \% CG = germination on control soil, GERm = elongation of root on contaminated soil, GERCm $=$ elongation of root on control soil.

\section{GC-MS analysis}

Analysis of the residual hydrocarbon in the soil was determined using GC (2010 A) coupled to a mass spectrophotometer QP2010 Plus. Helium carrier gas flow was $1.27 \mathrm{~mL} \mathrm{~min}^{-1}$. The column oven was initially held at $100{ }^{\circ} \mathrm{C}$ for 2 min then increased to $200{ }^{\circ} \mathrm{C}$ at a rate of $10{ }^{\circ} \mathrm{C} \mathrm{min}-1$, and further to $250^{\circ} \mathrm{C}$ at $20^{\circ} \mathrm{C} \mathrm{min}^{-1}$ (held for $5 \mathrm{~min}$ ) (Padayachee and Lin, 2011).

\section{Kinetics of diesel removal and Half- Life}

First- order kinetics model used is expressed by the following equation (Chu and Chan, 2003):

$\mathrm{C}_{\mathrm{t}}=\mathrm{C}_{\mathrm{i}} \exp (-k t)$

where $C_{t}\left(\mathrm{mg} \mathrm{g}^{-1}\right)$, is the diesel fuel concentration in soil at instant $t, C_{i}\left(\mathrm{mg} \mathrm{g}^{-1}\right)$ is the initial concentration of soil, $k$ is the rate constants of the first order expressed in (day ${ }^{-1}$ ) and $t$ is the time (Padayachee and Lin). The model estimated the biodegradation rate and half- life of hydrocarbons in soil relative to treatments applied.

Half life $=\ln 2 / k$

The data were analyzed for significant differences $(p<0.05)$ between treatments using one-way analyses of variance (ANOVA) with SPSS 18.

\section{RESULTS AND DISCUSSION}

Physicochemical properties of soil and organic wastes

The physicochemical properties of the investigated soil (silty loam) and biowastes used in this biodegradation study are presented in Table 1. It is clear that the soil had a low $N(0.8 \%)$ and $P$ $(0.6 \%)$ content compared to the organic wastes. The soil used for bioremediation had C: $\mathrm{N}$ ratio of 16.4. Röling et al. (2002) reported that stimulated biodegradation of hydrocarbons in soil amended with $2.5 \mathrm{~g}$ of $\mathrm{N}$ per kilogram gives $\mathrm{C}: \mathrm{N}$ ratio greater than 300 . This is a low ratio for effective biodegradation of oil in the soil, hence needed addition of organic wastes as a source of nutrient. Abioye et al., (2009a) recorded low percentage of organic carbon in the soil (0.8) compared to yellow melon shell and white melon shell amended with 1.06 and $1.08 \%$ of organic C, respectively. $\mathrm{SC}$ had the highest $\mathrm{N}$ and $\mathrm{P}$ content among the three organic wastes used; this is one of the most important limiting nutrients for effective bioremediation (Kim, 2005; Okoh, 2006). The moisture content SC $(75.9 \%)$ was higher than those of PS $(62.1 \%)$ and TL $(34.3 \%)$; this might enable SC to harbor some important microorganisms that will contribute positively to the biodegradation of oil in the soil. 
Table 1. Physicochemical properties of soil and organic wastes used for bioremediation

\begin{tabular}{lcccc}
\hline Parameters & Soil & TL & SC & PS \\
\hline Nitrogen (\%) & $0.8 \pm 0.1$ & $1.02 \pm 0.08$ & $1.3 \pm 0.1$ & $1.1 \pm 0.04$ \\
\hline Phosphorus (\%) & $0.6 \pm 0.5$ & $0.79 \pm 0.68$ & $0.9 \pm 0.9$ & $0.7 \pm 0.1$ \\
\hline Moisture content (\%) & $10.2 \pm 0.8$ & $34.3 \pm 0.5$ & $75.9 \pm 1.6$ & $62.1 \pm 2.03$ \\
\hline Organic C (\%) & $1.14 \pm 1.3$ & $0.89 \pm 1.2$ & $1.26 \pm 0.9$ & $1.15 \pm 1.1$ \\
\hline $\mathrm{pH}$ & $7.03 \pm 1.5$ & $6.5 \pm 1.2$ & $6.8 \pm 1.2$ & $6.9 \pm 0.5$ \\
\hline
\end{tabular}

TL: Tea Leaf, SC: Soy Cake, PS: Potato Skin

\section{Biodegradation of diesel fuel in soil}

The level of biodegradation of oil throughout this study is shown in Figures 1 and 2. The results demonstrated the high biodegradation rate of the diesel fuel (between $33 \%$ and $82 \%$ ) at the end of 126 days in soil contaminated with $10 \%$ diesel fuel. The percentage of biodegradation with $20 \%$ diesel fuel showed between $5 \%$ to $26 \%$. Abioye et al. (2010) reported that degradation of used lubricating oil using brewery spent grain was more than $90 \%$ within the same period. There was a rapid decrease in TPH of all the treated soils amended with organic wastes compared with unamended control soil. At the end of 56 days, there was $39 \%, 42 \%$ and $58 \%$ TPH reduction in soil amended with TL, PS and SC in soil amended with $10 \%$ oil respectively, compared to the control soil with $18 \%$ oil degradation (Figure 2). The reason for this relatively high and progressive biodegradation in all the soil contaminated with $10 \%$ diesel oil might be due to low concentration of oil compared with $20 \%$ oil in the soil which could pose serious challenge to the metabolic activities of the soil microorganisms. Also, it could also be due to the presence of organic waste amendments which likely provided nutrients to the microbial population present in the contaminated soil, thereby enabling them to degrade almost completely the oil contaminant.

Bartha (1986), reported that when oil is applied to soil at rates of 0.5 to $10 \%$ based on weight, extensive biodegradation of the oil components occurred within the first three months. Result indicated $9 \%$ and $4 \%$ of degradation in autoclaved control at 10 and $20 \%$ oil, respectively.

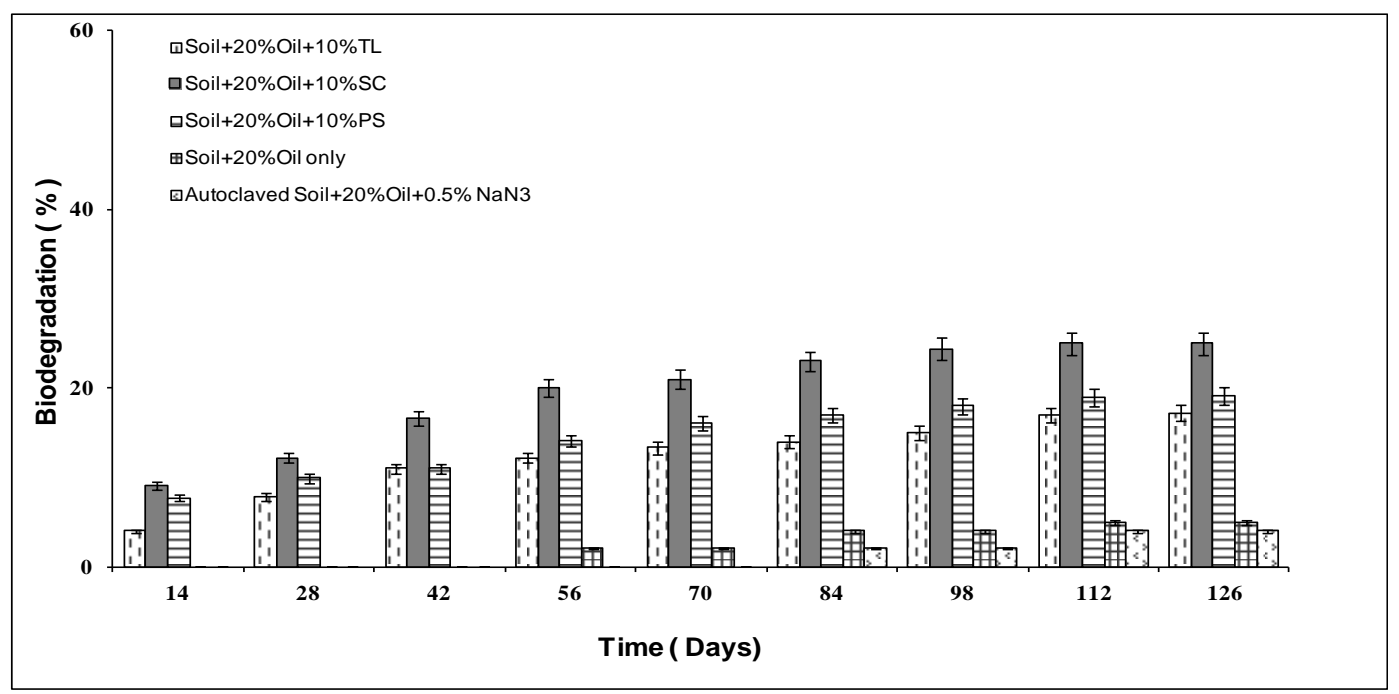

Figure 1. Biodegradation of soil amended with $10 \%$ organic waste and $20 \%$ diesel fuel. Error bars indicate standard errors $(n=3)$

It might be due to non-biological factors such as evaporation or photodegradation. This was based on poisoned control soil i.e. autoclaved contaminated soil treated with $0.5 \%$ sodium azide. This was contrary to the findings of Palmroth et al. (2002), who recorded as high as $70 \%$ diesel fuel loss within 28 days of study. The differences in these results might be because poisoned control in this study was autoclaved soil mixed with $0.5 \%$ sodium azide, whereas, Palmroth et al. (2002), used only $0.5 \%$ sodium azide without autoclaving the soil, thus the sodium azide possibly could not completely sterilize the soil. 
In soil contaminated with $20 \%$ oil, there were $26 \%, 20 \%$, and $17 \%$ TPH degradation in soil amended with SC, PS, and TL, respectively. The reason for the low oil degradation be attributed to the toxicity of the oil on the microbial flora of the soil, due to high concentration of oil which propably had a negative effects on the biodegradative activities of the microbial population. However, there are significantly differences among organic wastes and control during the degradation period. Results indicate that the degradation of oil in soil amended with SC was significant different with soil amended compared to PS and TL $(p<0.05)$. Similar results were obtained by Adesodun and Mbagwu (2008), who reported significant differences between the soils amended with cow dung and poultry manure in soil polluted with crude oil.

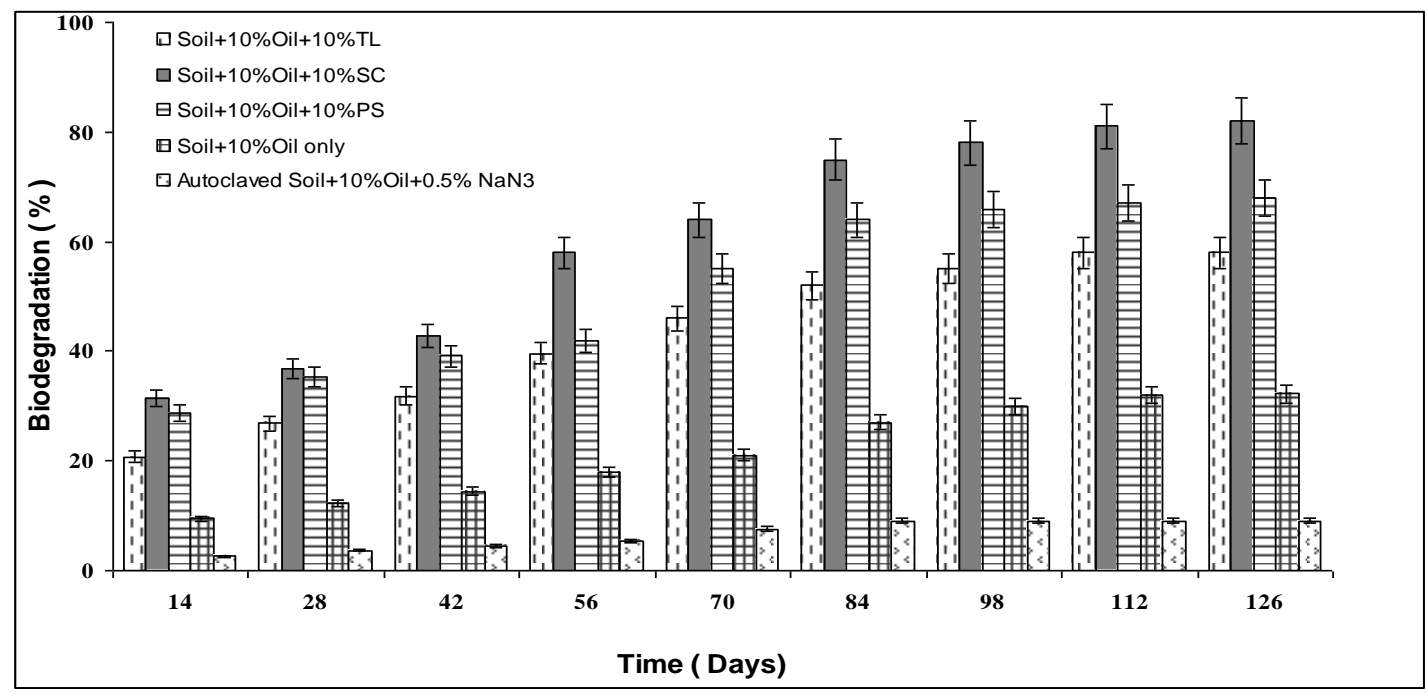

Figure 2. Biodegradation of soil amended with $10 \%$ organic waste and $10 \%$ diesel fuel. Error bar indicate standard errors $(n=3)$

The highest loss of TPH was recorded in SC amended soil during the 126 days, followed by PS and TL. This may be due to the presence and bioavailability of nutrient elements like $N(1.3 \%)$ and $P$ $(0.9 \%)$ in SC (Table 1). Nitrogen is known as one of the limiting nutrient necessary for biodegradation of organic pollutants in soil (Barahona et al., 2005). It is also supported by the findings of Joo et al. (2007), who observed that the addition of food waste compost to contaminated soil, leads to increase in the rate of removal of diesel fuel in the soil. However, the rate of oil breakdown in soil amended with TL was lower than other organic wastes, which may be due to low $\mathrm{pH}$ recorded in soil treated with TL throughout this study. Low $\mathrm{pH}$ is known to affect the rate of oil breakdown by bacteria in oil contaminated soil (Okoh, 2006). The decrease in the degradation rates were associated with increased oil concentrations (ljah and Antai, 2003b).

\section{Microbial population}

Active aerobic heterotrophic bacterial colonies (AHB) were recorded in SC treated soil, ranging from $11 \times 10^{7}$ to $141 \times 10^{7} \mathrm{CFU} \mathrm{g}{ }^{-1}$, while AHB counts in PS and TL ranged between $8 \times 10^{7}$ and $115 \times 10^{7}$ CFU g ${ }^{-1}$ and $10 \times 10^{7}$ to $122 \times 10^{7} \mathrm{CFU} \mathrm{g} \mathrm{g}^{-1}$ of polluted soil with $10 \%$ oil, respectively (Figure 3 ). Unamended soil (control) gave a range of $1 \times 10^{7}$ to $20 \times 10^{7} \mathrm{CFU} \mathrm{g^{-1 }}$ of soil, which is in line to the findings of (ljah and Antai, 2003b). It was reported by Hinchee (1995), that when the population of microorganisms capable of degrading the target contaminant is less than $10^{5}$ colony-forming units (CFU g ${ }^{-1}$ of soil), bioremediation will not occur at a significant rate. However, at the end of the experiment, soil amended with $20 \%$ diesel fuel SC recorded higher number of colony $\left(70 \times 10^{7} \mathrm{CFU}\right.$ $\mathrm{g}^{-1}$ ) compared to other treatments and the control treatment. Statistical analysis showed that there was significant difference between treatments and control at $(p<0.05)$. DUB isolated ( Bacillus licheniformis, Bacillus circulans, Ochrobactrum tritici and Staphylococcus acidaminiphila) from the oil contaminated soil were identified by using Biolog methods.

These bacteria species had been identified in organic compound degradation by different researchers (Abioye et al., 2009; Bento et al., 2005; Margesin et al., 2007). 


\section{Germination toxicity test and Seed Germination Index}

The results of germination toxicity test with lettuce for soil amended with $10 \%$ and $20 \%$ diesel fuel are shown in Tables 2 and 3. Lettuce is sensitive to toxic chemicals (mostly petroleum contaminants) and it is an important agricultural crop, which led to its wide use for toxicity tests (Banks and Schultz, 2005; Oleszczuk, 2008). The results indicated $90 \%, 70 \%$, and $60 \%$ germination in soil contaminated with $10 \%$ oil amended with SC, PS, and TL, respectively.

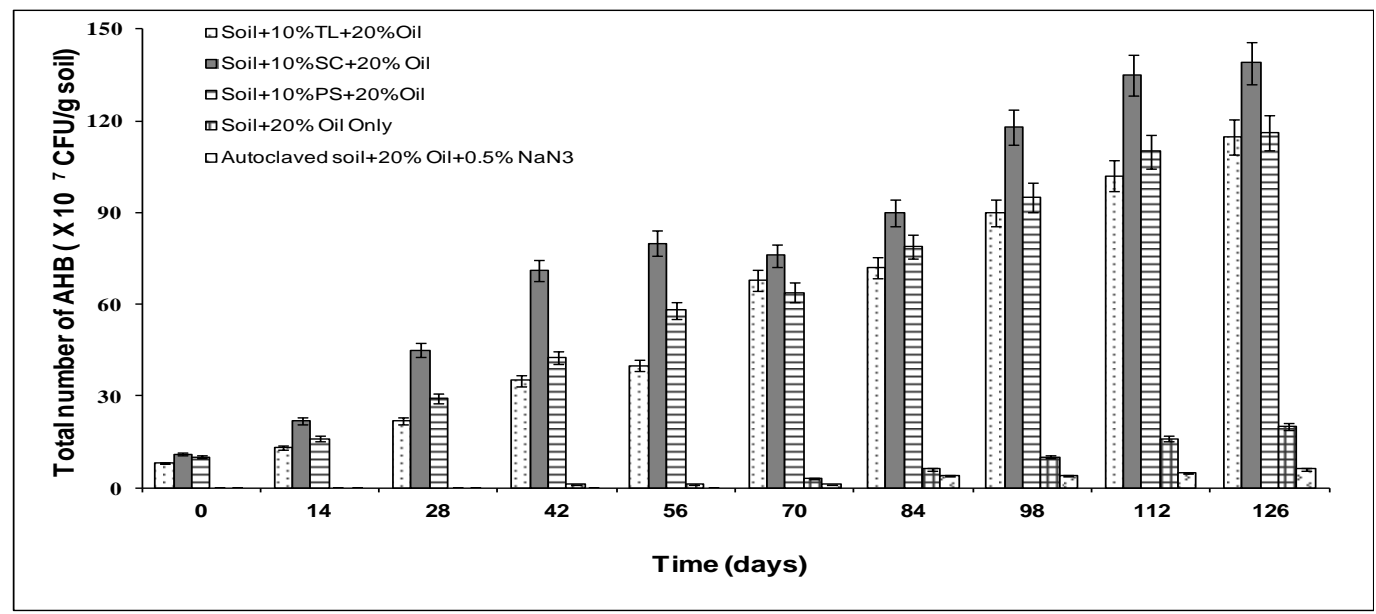

Figure 3. Aerobic heterotrophic bacteria (AHB) population in 10\% diesel fuel polluted soil. Vertical bars indicate SE $(n=3)$

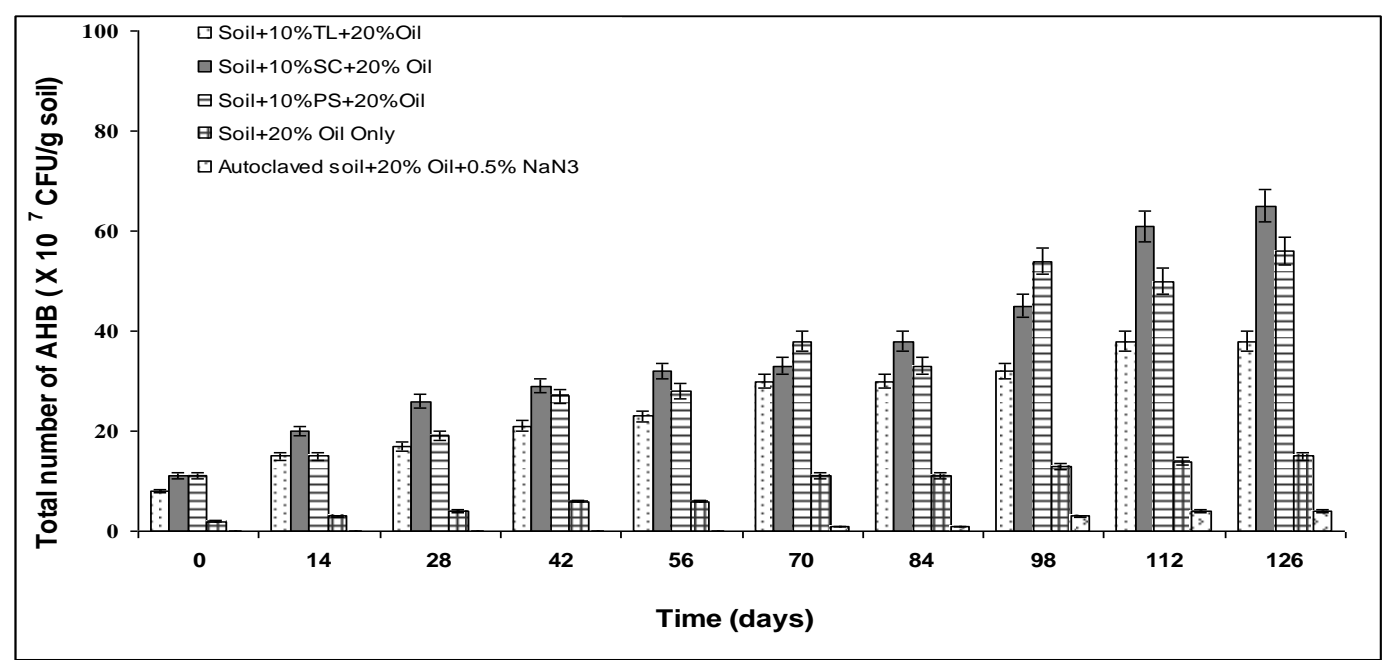

Figure 4. Aerobic heterotrophic bacteria (AHB) population in $20 \%$ diesel fuel polluted soil. Vertical bars indicate SE $(n=3)$

Table 2. Seed germination (\%) toxicity test with $10 \%$ organic waste amendments

\begin{tabular}{ccccccc}
\hline $\begin{array}{c}\text { Percentage } \\
\text { of oil } \\
\text { pollution }\end{array}$ & $\mathrm{A}$ & $\mathrm{B}$ & $\mathrm{C}$ & $\mathrm{D}$ & $\mathrm{E}$ & $\mathrm{F}$ \\
\cline { 2 - 7 } & $60 \pm 8$ & $90 \pm 10$ & $70 \pm 7$ & $30 \pm 5$ & 0 & 100 \\
\hline 10 & $20 \pm 6$ & $40 \pm 6$ & $20 \pm 5$ & $10 \pm 5$ & 0 & 100 \\
\hline 20 & &
\end{tabular}

$A=$ Soil + Oil + TL, B = Soil + Oil + SC, C = Soil + Oil + PS, D = Soil + Oil, E = Autoclaved soil + Oil $+\mathrm{NaN}_{3}, \mathrm{~F}=$ Uncontaminated soil

However, $40 \%, 20 \%$, and $20 \%$ seed germination were recorded in soil contaminated with $20 \%$ oil and amended with SC, PS, and TL, respectively. $100 \%$ germination was recorded in uncontaminated control soil, while $0 \%$ was recorded in poisoned controlled soil in both diesel oil 
concentrations. The result shows positive correlation between loss of oil in the remediated soil and seed germination. It was also obvious that remediation of soil contaminated with high concentration of petroleum hydrocarbons needed a longer period of time. Bank and Schultz (2005) and Millioli et al. (2009) recorded a decrease in the number of germinated seeds with increased quantities of petroleum concentration in the soil. Germination index (GI) of soil treated with SC recorded the highest value (63.33 and 10) in soil amended with 10 and $20 \%$ oil (Table 3). However, the Gl of unamended polluted soil and that of amended soil contaminated with $20 \%$ diesel oil was very low, signifying low biodegradation of oil in this treatment. Hydrocarbons may affect root surface, preventing or reducing gas and water exchange and nutrient absorption. They may also enter the seeds and alter the metabolic reactions and kill the embryo. Hydrocarbons damage cell membranes and reduces the metabolic transport and respiration rate (Ogboghodo et al., 2004; Oleszczuk, 2008).

Table 3. Seed germination (\%) index test with $10 \%$ organic waste amendments

\begin{tabular}{cccccc}
\hline $\begin{array}{c}\text { Percentage } \\
\text { of oil } \\
\text { pollution }\end{array}$ & A & B & C & D & E \\
\cline { 2 - 6 } & 34.33 & 63.33 & 40.00 & 12.34 & 0 \\
\hline 20 & 2.3 & 10.00 & 6.67 & 1.06 & 0 \\
\hline $\begin{array}{c}A=\text { Soil }+ \text { Oil+ TL, } \\
\text { E }=\text { Autoclaved soil }+ \text { Oil }+\mathrm{NaN}_{3}\end{array}$ & & &
\end{tabular}

\section{Microbial activity and soil respiration}

Dehydrogenase enzyme activity has been used to monitor microbial activity as an index for the total oxidative activity (Alef, 1995). At the second sampling (42-d), dehydrogenase activity of the contaminated soil with SC showed a value significantly (2.2 -fold) higher than that of uncontaminated soil at $10 \%$ oil concentration. This may be an evidence that high intensity of microbial activity took place at the initial stage of degradation, which could have efficiently utilized organic carbon of TPH. Therefore, dehydrogenase activity may be used as a parameter representing microbial activity. At the end of the experiment all of the amendments showed a decrease in microbial activity, this final decrease indicated the lack of optimum growth conditions for microorganisms. Increase in microbial activity in this research indicates that the high population of organisms in those treatments which were amended with organic wastes is metabolically more active and may contribute to the biodegradation process of TPH, compared to unamended treatments (Lee et al., 2008). These results is similar to the findings of Margenis et al. (2000) who reported an initial phase characterized by an increase in dehydrogenase activity in hydrocarbon contaminated soils. $\mathrm{CO} 2$ evolution has been used as an index representing microbial activity, because $\mathrm{CO} 2$ is a by-product of organic compound degradation. The cumulative amount of $\mathrm{CO} 2$ evolved shows more distinct effect of organic amendments on TPH degradation. The metabolic activity (respiration) of microbes increased significantly. Dramatic increase in $\mathrm{CO} 2$ evolution at early stage was probably due to the rapid degradation of TPH at the same period. In treatments (TL, SC and PS), where hydrocarbons were added to soil, except for the sterilized contaminated soil (SCS), it was possible to observe significantly higher values for CO2. Tables 4 and 5 showed the correlation coefficients for TPH degraded, cumulative $\mathrm{CO} 2$ evolved and dehydrogenase activity. Degradation of TPH was significantly related to microbial respiration as measured by $\mathrm{CO} 2$ evolution $(r=0.91, P \leq 0.01)$ at $10 \%$ oil pollution. High positive correlation was also found between TPH degraded and dehydrogenase activity.

Table 4. Matrix of correlation coefficients for the parameters used in this research at $10 \%$ diesel fuel

\begin{tabular}{cccc}
\hline & TPH degraded & Cumulative $\mathrm{CO}_{2}$ & Dehydrogenase activity \\
\hline TPH degraded & 1.00 & $0.91^{* *}$ & $0.89^{* *}$ \\
\hline $\mathrm{CO}_{2}$ & 1.00 & $0.91^{* *}$ \\
\hline $\begin{array}{c}\text { Dehydrogenase } \\
\text { activity }\end{array}$ & & 1.00 \\
${ }^{* *}$ Correlation is significant at the 0.01 level & &
\end{tabular}


Table 5. Matrix of correlation coefficients for the parameters used in this research at $20 \%$ diesel fuel

\begin{tabular}{cccc}
\hline & TPH degraded & Cumulative $\mathrm{CO}_{2}$ & Dehydrogenase activity \\
\hline TPH degraded & 1.00 & $0.92^{* *}$ & $0.91^{* *}$ \\
\hline $\mathrm{CO}_{2}$ & 1.00 & $0.89^{* *}$ \\
\hline $\begin{array}{c}\text { Dehydrogenase } \\
\text { activity }\end{array}$ & & 1.00 \\
${ }^{* *}$ Correlation is significant at the 0.01 level & &
\end{tabular}

\section{GC-MS analysis}

The residual oil was analyzed and identified from their mass spectra and retention times, as indicated by the chromatogram of the remaining diesel after biodegradation tests. Hydrocarbons above $\mathrm{C}_{14}$ adsorbed to the soil particle, which makes them less volatile, and they do not give a detectable concentration in the gas phase when sampling times are as short as those used in this experiment (Dalhammar, 1998). Significant reduction in diesel content $\left(\mathrm{C}_{8}-\mathrm{C}_{26}\right)$ was observed in the biostimulation samples compared to the natural attenuation and the sterilized controls. A decrease in the intensities of hydrocarbon in all supplemented treatments and natural attenuation were observed, compared with those in the sterilized samples (Figure 5). The peaks of long-chain petroleum hydrocarbons were relatively higher than those of short chain hydrocarbons. Similar results were shown by (Huang et al., 2005).

\section{Kinetics of diesel removal and Half-life}

First- order kinetics model proposed by Chu and Chan (2003), was used for determination of biodegradation of used oil in the various treatments. Table 6 , shows the biodegradation rate constant $(k)$ and half-life $\left(t_{1 / 2}\right)$ for the different treatments. Soil amended with SC had the highest biodegradation rate of 0.153 day ${ }^{-1}$ and half life 4.53 days at $10 \%$ concentration of diesel oil; the biodegradation rate and half-life of PS and TL were 0.115 day ${ }^{-1}$, half-life 6.02 days and 0.076 day ${ }^{-1}$, half-life 9.12 days at $10 \%$ concentration oil, respectively. The biodegradation rate of unamended control and autoclaved soil were observed to be 0.037 day $^{-1}$ and 0.01 day $^{-1}$. It has been reported by Namkoong et al. (2002) that higher biodegradation rate constant and low half-life in diesel contaminated soil were observed in 1:0.3 sewage sludge compared to those amended with 1:0.1 under the same conditions. Adesodun and Mbagwu (2008), reported that biodegradation rates in oil contaminated soil, amended with pig wastes, showed highest percentage of biodegradation throughout the study period.

Table 6. Biodegradation rate and half-life of hydrocarbon for oil-polluted soil

\begin{tabular}{lccc}
\hline \multicolumn{1}{c}{ Treatment } & $\begin{array}{c}\text { Biodegradat } \\
\text { constant }(\mathrm{k}) \\
\text { day }^{-1}\end{array}$ & $\begin{array}{c}\text { Half- life ( days) } \\
\mathrm{t}_{1 / 2}\end{array}$ & $\begin{array}{c}\text { Coefficients of } \\
\text { determination }\left(\mathrm{r}^{2}\right)\end{array}$ \\
\hline Soil+10\%Oil+TL & 0.076 & 9.12 & 0.92 \\
\hline Soil+10\%Oil+SC & 0.153 & 4.53 & 0.97 \\
\hline Soil+10\%Oil+PS & 0.113 & 6.02 & 0.90 \\
\hline Soil+10\% Oil & 0.037 & 18.74 & 0.94 \\
\hline Autoclaved soil + 10\% & 0.010 & 64.78 & 0.89 \\
\hline Soil+20\%oil+TL & 0.019 & 35.36 & 0.90 \\
\hline Soil+20\%Oil+SC & 0.033 & 21.00 & 0.88 \\
\hline Soil+20\%Oil+PS & 0.025 & 27.50 & 0.85 \\
\hline Soil+20\% Oil & 0.001 & 70.73 & 0.91 \\
\hline Autoclaved soil + 20\% & 0.001 & 630.13 & 0.98 \\
\hline
\end{tabular}

* Shows significant difference at the $p<0.05$ level respectively. 
a)

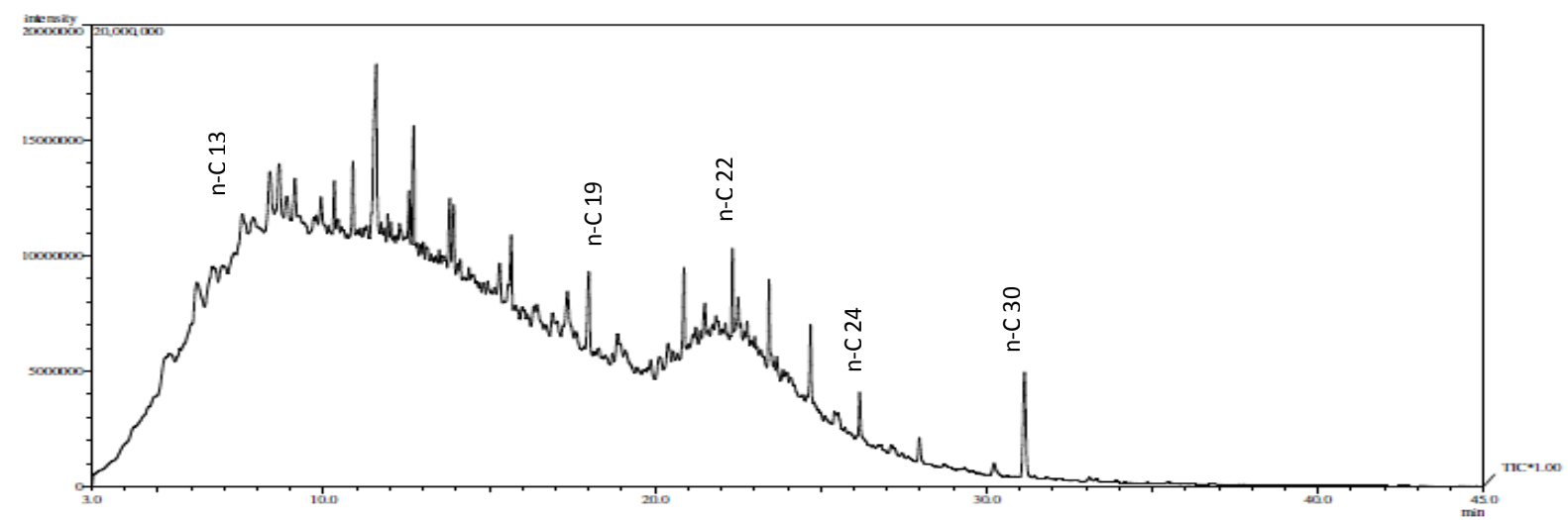

b)

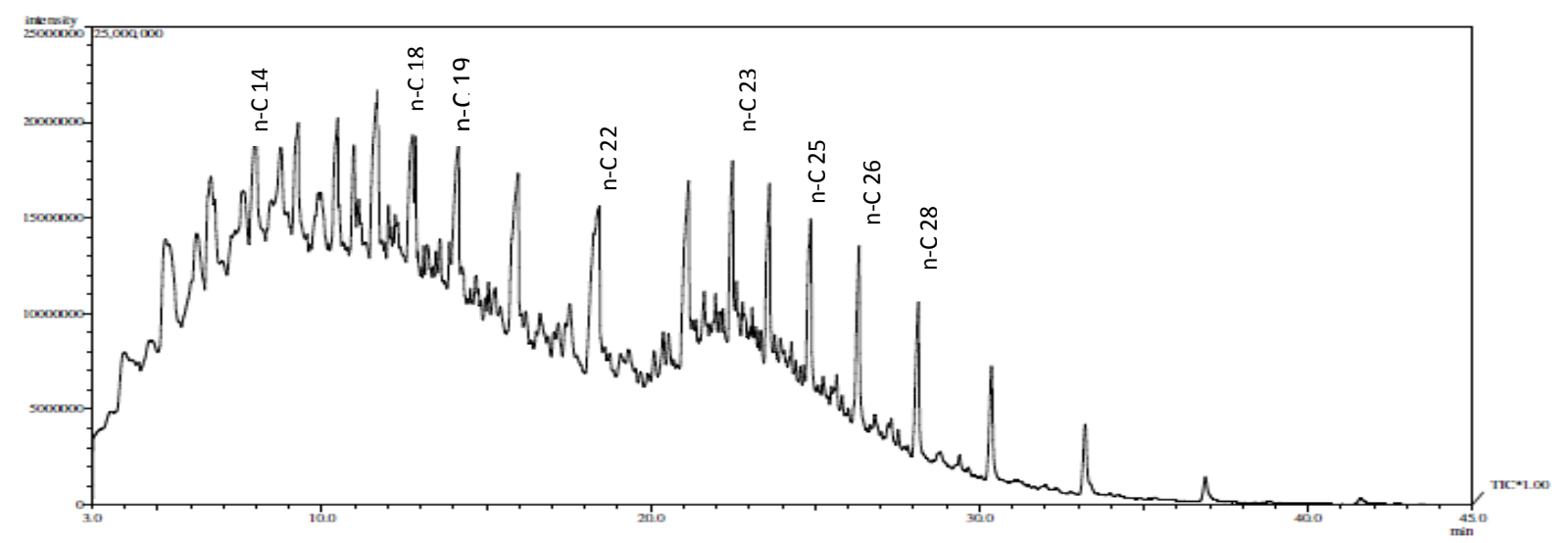

c)

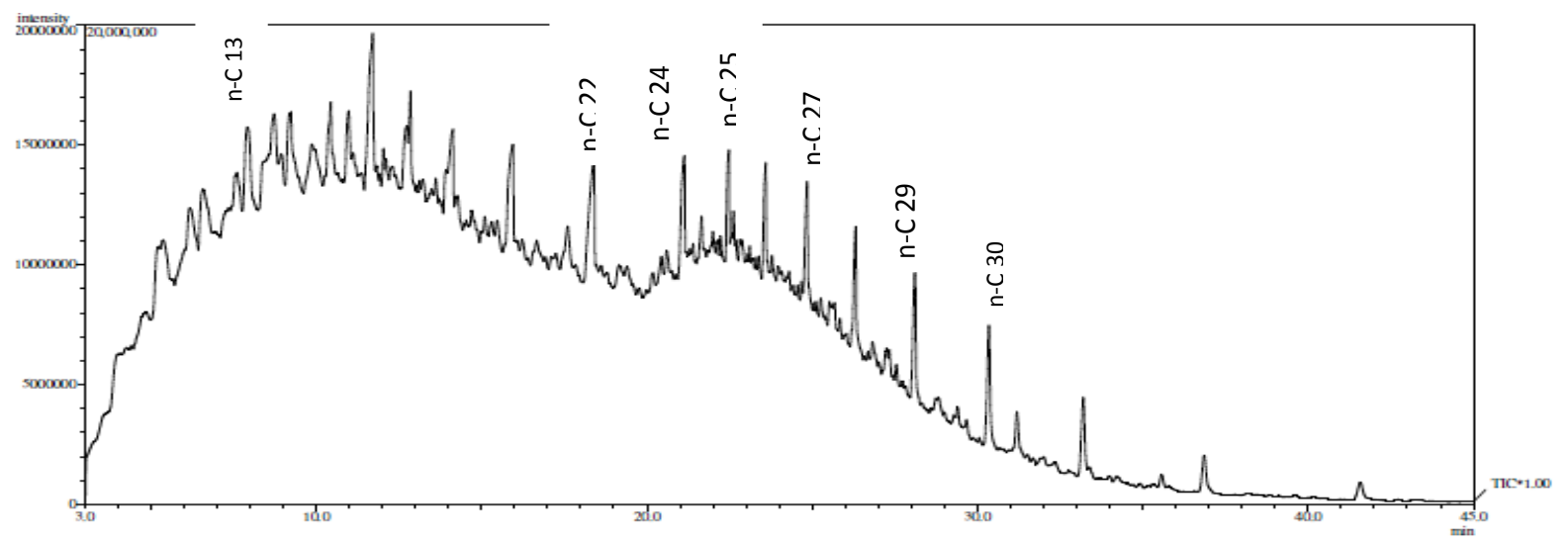

Figure 5. Chromatogram of residual diesel fuel in soil amended with SC at the end of experiment a) $10 \%$ oil concentration, b) $20 \%$ oil concentration and

c) control at 0 day.

\section{CONCLUSION}

The results of this study demonstrated the potential of organic wastes amendments to remediate hydrocarbons contaminated soil. In this study, a significant reduction in diesel fuel was achieved by adding soy cake, which is a waste from soy bean processing, possibly because it was more effective than other amendments in providing an alternative source of $\mathrm{N}$ and $\mathrm{P}$, to stimulate microbial activity. High correlation $(r=0.91,0.89)$ was found among the amount of TPH degraded, the amount of $\mathrm{CO}_{2}$ evolved, and dehydrogenase activity at $10 \%$ oil. The study therefore proves the viability of using SC amendment in remediating hydrocarbon-contaminated soil. This affords an alternative method in 
removing oil contaminants from soil. Kinetic model data in this study showed that the rate of degradation of diesel oil in soil amended with SC was higher than all other treatments. Overall, the differential performance of these organic amendments followed SC > PS > TL.

ACKNOWLEDGMENTS: This study was supported with the University of Malaya IPPP Grants FP014/2010A, PV055/2011 B and PS300/ 2010B.

\section{REFERENCES}

Abioye O.P., Alonge O.A. and ljah U.J.J. (2009a), Biodegradation of Crude Oil in Soil Amended with Melon Shell, AU Journal of Technology, 13(1), 35-38.

Abioye P., Abdul Aziz A. and Agamuthu P. (2009b), Enhanced Biodegradation of Used Engine Oil in Soil Amended with Organic Wastes, Water, Air, \& Soil Pollution, 209(1), 173-179.

Adesodun J.K. and Mbagwu J.S.C. (2008), Biodegradation of waste-lubricating petroleum oil in a tropical alfisol as mediated by animal droppings, Bioresource Technology, 99(13), 5659-5665.

Akinde S. and Obire O. (2008), Aerobic heterotrophic bacteria and petroleum-utilizing bacteria from cow dung and poultry manure, World Journal of Microbiology and Biotechnology, 24(9), 1999-2002.

Alef K. (1995). Estimation of microbial activities: dehydrogenase activity. In: Methods in Applied Soil Microbiology and Biochemistry, Alef K., Nannipieri P. (Eds), Academic Press, New York, 228231.

Antai S.P. and Mgbomo E. (1989), Distribution of hydrocarbon utilizing bacteria in oil-spill areas, Microbios Letters, 40, 137-143.

Bamforth S.M. and Singleton I. (2005), Bioremediation of polycyclic aromatic hydrocarbons: current knowledge and future directions, Journal of Chemical Technology and Biotechnology, 80, 723736.

Banks M.K. and Schultz K.E. (2005), Comparison of plants for germination toxicity test in petroleum contaminated soil, Water, Air, and Soil Pollution, 167, 211-219.

Barahona L., Veg-Loyo L., Guerrero M., Ramirez S., Romero I. and Vega-Jarquin C. (2005), Ecotoxicological evaluation of diesel-contaminated soil before and after bioremediation process, Environmental Toxicology, 20(1), 100-109.

Bento F.M., Camargo F.A.O., Okeke B.T.C. and Frankenberger W.T. (2005), Comparative bioremediation of soils contaminated with diesel oil by natural attenuation, biostimulation and bioaugmentation, Bioresource Technology, 96(9), 1049-1055.

Chu W. and Chan K.H. (2003), The mechanism of the surfactant-aided soil washing system for hydrophobic and partial hydrophobic organics, The Science of The Total Environment, 307(1-3), 83-92.

Collin P.H. (2001), Dictionary of Ecology and the Environment, fourth ed. Peter Collin Publishing, London.

Dadrasnia A. and Agamuthu P. (2010), Enhanced Degradation of Diesel-Contaminated Soil using Organic Wastes, Malaysian Journalof Science, 29, 225-230.

Dalhammar M.E. (1998), Biological degradation of diesel fuel in water and soil monitored with solid-phase micro-extraction and GC-MS, Appl Microbiol Biotechnol, 50, 129-134.

EIA (2011), China electricity U.S.Energy Information Agency http://eia.doe.gov/cabs/china/electricity.htm.

Hamdi H., Benzarti S., Manusadzianas L., Aoyama I. and Jedidi N. (2007), Bioaugmentation and biostimulation effects on PAH dissipation and soil ecotoxicity under controlled conditions, Soil Biology and Biochemistry, 39(8), 1926-1935.

Huang X.-D., El-Alawi Y., Gurska J., Glick B.R. and Greenberg B.M. (2005), A multi-process phytoremediation system for decontamination of persistent total petroleum hydrocarbons (TPHs) from soils, Microchemical Journal, 81(1), 139-147.

ljah U.J.J. and Antai S.P. (2003a), The Potential Use of Chicken-Drop Micro-Organisms for Oil Spill Remediation, The Environmentalist, 23(1), 89-95.

ljah U.J.J. and Antai S.P. (2003b), Removal of Nigerian light crude oil in soil over a 12-month period, International Biodeterioration \& Biodegradation, 51(2), 93-99. 
ljah U.J.J. and Ukpe L.I. (1992), Biodegradation of crude oil by bacillus strains 28A and 61B isolated from oil spilled soil, Waste Management, 12(1), 55-60.

Lee S.-H., Oh B.-I. and Kim J.-G. (2008), Effect of various amendments on heavy mineral oil bioremediation and soil microbial activity, Bioresource Technology, 99(7), 2578-2587.

Manuela T., Vesna M., Francesca C., Cristiano C.B. and Maurizio C. (2012), Effects of biostimulation and bioaugmentation on diesel removal and bacterial community, International Biodeterioration \& Biodegradation, 66, 39-46.

Margesin R. and Schinner F. (Eds.) (2005), Manual of soil analysis-Monitoring and assessing soil bioremediation, Soil biology, vol 5, Springer, Austria.

Margesin R., Hämmerle M. and Tscherko D. (2007) Microbial Activity and Community Composition during Bioremediation of Diesel-Oil-Contaminated Soil: Effects of Hydrocarbon Concentration, Fertilizers, and Incubation Time, Microbial Ecology, 53(2), 259-269.

Miles R.A. and Doucette W.J. (2001). Assessing the aerobic biodegradability of 14 hydrocarbons in two soils using a simples microcosm/respiration method, Chemosphere, 45, 1085-1090.

Millioli V.S., Servulo E.L.C., Sobral L.G.S. and Carvalho D.D. (2009), Bioremediation of crude oil bearing soil: evaluating the effect of rhamnolipid addition to soil toxicity and to crude oil biodegradation efficiency, Global NEST Journal, 11(2), 181- 188.

Namkoong W., Hwang E.-Y., Park J.-S. and Choi J.-Y. (2002), Bioremediation of diesel-contaminated soil with composting, Environmental Pollution, 119(1), 23-31.

Ogboghodo I.A., Iruaga E.K., Osemwota I.O. and Chokor J.U. (2004), An assessment of the effects of crude oil pollution on soil properties, germination and growth of maize (zea mays) using two crude types_forcadors light and escravos light, Environmental Monitoring and Assessment, 96, 143-152.

Okoh I.O. (2006), Biodegradation alternative in the cleanup of petroleum hydrocarbon pollutants, Biotechnology and Molecular Biology Review, 1(2), 38-50.

Oleszczuk P. (2008), hytotoxicity of municipal sewage sludge composts related to physicochemical properties, PAHs and heavy metals, Ecotoxicology and Environmental Safety, 69, 496-505.

Padayachee D. and Lin J. (2011), The effect of fertilizer amendment on diesel biodegradation in contaminated soils, African Journal of Microbiology Research, 5(14), 1729-1739.

Pankrantz T.M. (2001), Environmental Engineering Dictionary and Directory. CRC Press, Boca Raton, FL.

Röling W.F., Milner M.G., Jones D.M., Lee K., Daniel F., Swannell R.J., Head I.M. (2002), Robust hydrocarbon degradation and dynamics of bacterial communities during nutrient-enhanced oil spill bioremediation, Applied And Environmental Microbiology, 68(11):5537-5548

Ruan A., Min H., Peng X. and Huang Z. (2005), Isolation and characterization of Pseudomonas sp. strain HF-1, capable of degrading nicotine, Research in Microbiology, 156(5-6), 700-706.

Selina M.B. and Ian S. (2005), Bioremediation of polycyclic aromatic hydrocarbons: current knowledge and future directions, Journal of Chemical Technology and Biotechnology, 8, 723-736.

Taccari M., Milanovic V., Comitini F., Casucci C. and Ciani M. (2012), Effects of biostimulation and bioaugmentation on diesel removal and bacterial community, International Biodeterioration \& Biodegradation, 66(1), 39-46.

Zajic J.E. and Supplisson B. (1972), Emulsification and degradation of "Bunker C" fuel oil by microorganisms, Biotechnology and Bioengineering, 14(3), 331-343. 